\title{
Confidential Information
}

Final Technical/Scientific Report DOE Grant: DE-SC0003653

Full Project Period: May, 1, 2010 through January 31, 2011

DE-SC0003653

SUPPORT FOR STUDENTS AND YOUNG SCIENTISTS TO PARTICIPATE IN THE AMERICAN CHEMICAL SOSIETY SYMPOSIUM ENTITLED LANHTANIDES AND ACTINIDES: A CHEMISTS'S PERSPECTIVE MARCH 21-25, 2010 HELD IN SAN FRANCISCO, CA

Curators of the University of Missouri 310 Jesse Hall

Columbia, Missouri 65211

Final Report

Cathy S. Cutler, Principal Investigator

UNIVERSITY OF MISSOURI RESEARCH REACTOR

University of Missouri-Columbia

Columbia, Missouri 65211-3400

Distribution:

Lester Morss, DOE-Heavy Metal; DOE Contracting Officer; Capital Accounting Center J. Cirkl, UM Office of Sponsored Programs Administration 


\section{Confidential Information}

Final Technical/Scientific Report DOE Grant: DE-SC0003653

Full Project Period: May, 1, 2010 through January 31, 2011

DOE Award DE-SC0003653 of \$6,000.00 was used to support early career scientist to attend the Lanthanide and Actinide Symposium at the ACS meeting in March in San Francisco 2010. The award was for $\$ 6,000.00$ and was used to support 12 early career scientists at $\$ 500.00 /$ each.

A committee was established comprised of the following individuals who aided in drafting the DOE award notice and in selecting the candidates to receive the awards: Ken Nash, Washington State University, (separations, environment); Mark Antonio, Argonne National Laboratory,(separations, environmental); Claude Meares, UC Davis, (medical, coordination chemistry); Lynn Francesconi, Hunter College, (coordination chemistry, theory, environment); Notker Roesch, University of Munich, (quantum chemistry, catalysis); Silvia Jurisson, University of Missouri, (inorganic chemistry, medical, environmental); and Cathy Cutler, MU Research Reactor Center, (inorganic chemistry, medical, pharmacology).

Below is the Notice that was sent out:

\section{DOE Award}

Students or early career scientists at US institutions who are accepted for a poster or oral presentation at the $239^{\text {th }}$ American Chemical Society Symposium “Lanthanides and Actinides: a Chemist's Perspective" are eligible to apply for funding to cover travel expenses to attend the meeting. Funding will be up to $\$ 500$ for each person selected for the award; the amount is dependent on travel distance. Successful applicants will require a letter from their mentor committing them to provide the additional funds for the trainee to present their work at the meeting (oral or poster presentation). 


\section{Confidential Information}

Final Technical/Scientific Report DOE Grant: DE-SC0003653

Full Project Period: May, 1, 2010 through January 31, 2011

The applicant should submit their abstract for the meeting, a CV and maximum of a one page summary of their reason for applying and the estimated total cost [including the itinerary] to attend the meeting. It is important that the trainee commit to participating in most of the meeting, ideally, the entire meeting. All funds will be presented to the successful applicants in San Francisco.

Please email your application to CutlercACS@missouri.edu with the Subject Line: ACS DOE Award. The deadline for application is February 28, 2010.

Funding for this award is provided by the US Department of Energy, Office of Science Financial Assistance Program (Funding Opportunity Number DE-FG0210ER16133).

From the many applications sent the review committee selected those listed below as the award recipients. Each recipient received a check for $\$ 500.00$ using the entire funds awarded to support travel to attend the meeting. 


\section{Confidential Information}

Final Technical/Scientific Report DOE Grant: DE-SC0003653

Full Project Period: May, 1, 2010 through January 31, 2011

\section{DOE Award Recipients}

Award Recipients

Shuao Wong

Shannon Thompson

Elizabeth Montalvo

Ben Schmiege

Thomas Mueller

Troy Robinson

Jenifer Braley

Clare Rowland

Jadwiga Kuta

Eric Weis

Pius Adelani

Keri Campbell
Advisors

Thomas E. Albrecht-Schmitt

Fred Molz

William J. Evans

William J. Evans

William J. Evans

Ken Czerwinski

Ken Nash

Christopher L. Cahill

Aurora Clark

Silvia Jurisson

Thomas E. Albrecht-Schmitt

Dr. Patricia Paviet-Hartmann UNLV
Institutions

Notre Dame

Clemson

UCI

UCI

UCI

UNLV

WSU

GWU

WSU

Missouri

Notre Dame 